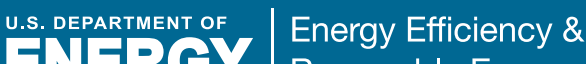
ENIRCY Renewable Energy
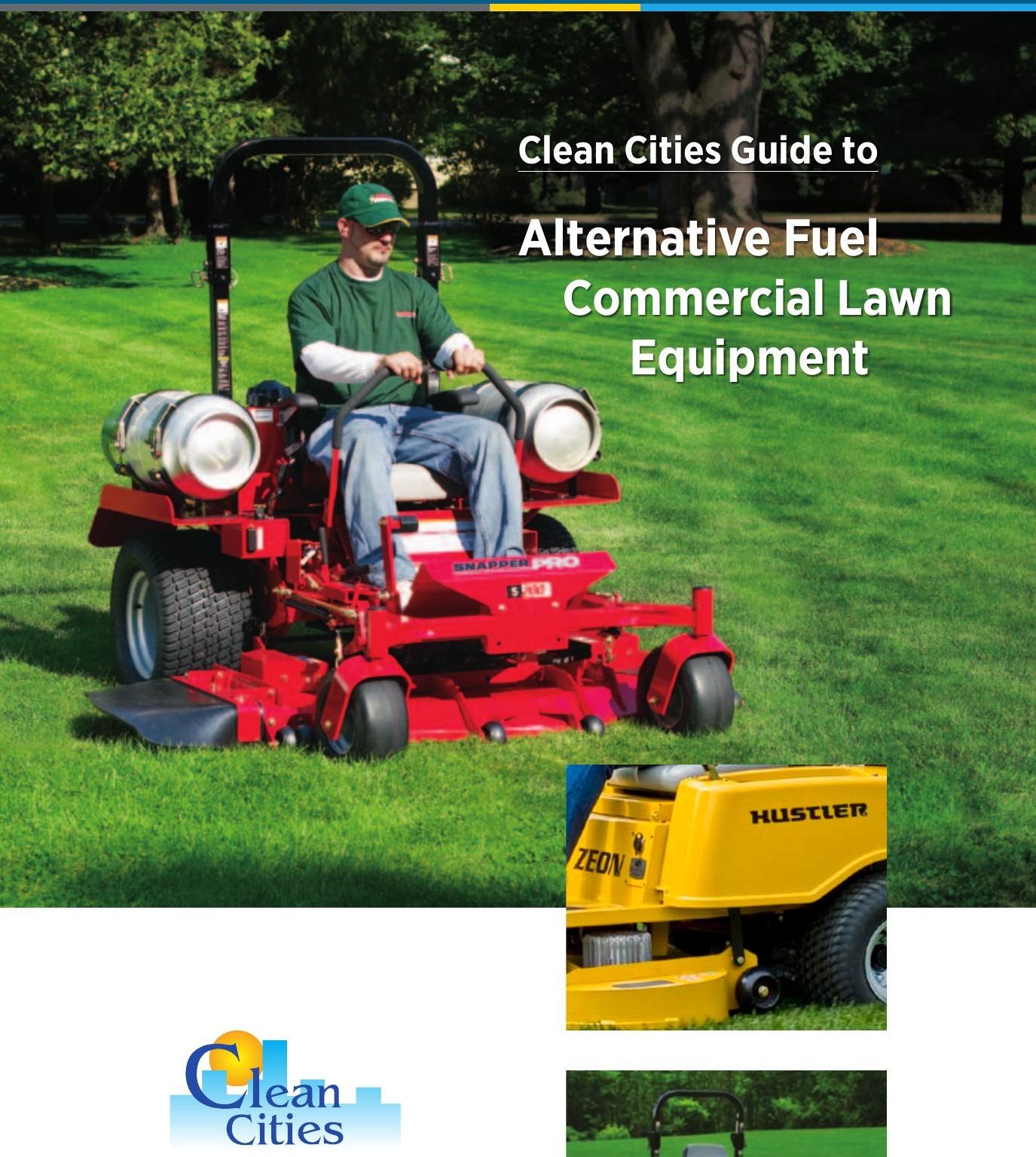

U.S. Department of Energy

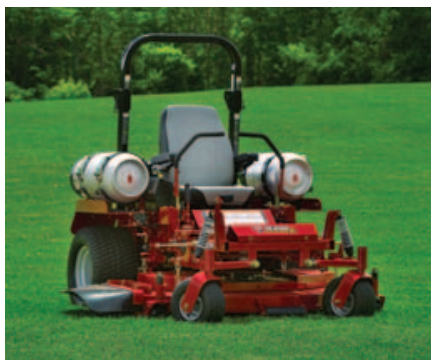





\section{Clean Cities Guide to}

\section{Alternative Fuel Commercial Lawn Equipment}

A single commercial lawnmower can annually use as much gasoline or diesel fuel as a commercial work truck. Powering commercial lawn service equipment with alternative fuels is an effective way to reduce petroleum use.

\section{Contents}

Introduction 4

Compressed

Natural Gas.......................... 6

Biodiesel................................. 6

Electricity .................................. 7

Propane ................................... 8

Incentives ................................ 14

Special Considerations ...... 14

Resources 15 Alternative fuels can also reduce pollutant emissions compared with conventional fuels. Numerous biodiesel, compressed natural gas, electric, and propane mowers are available to help keep the grass green and the nation clean. 


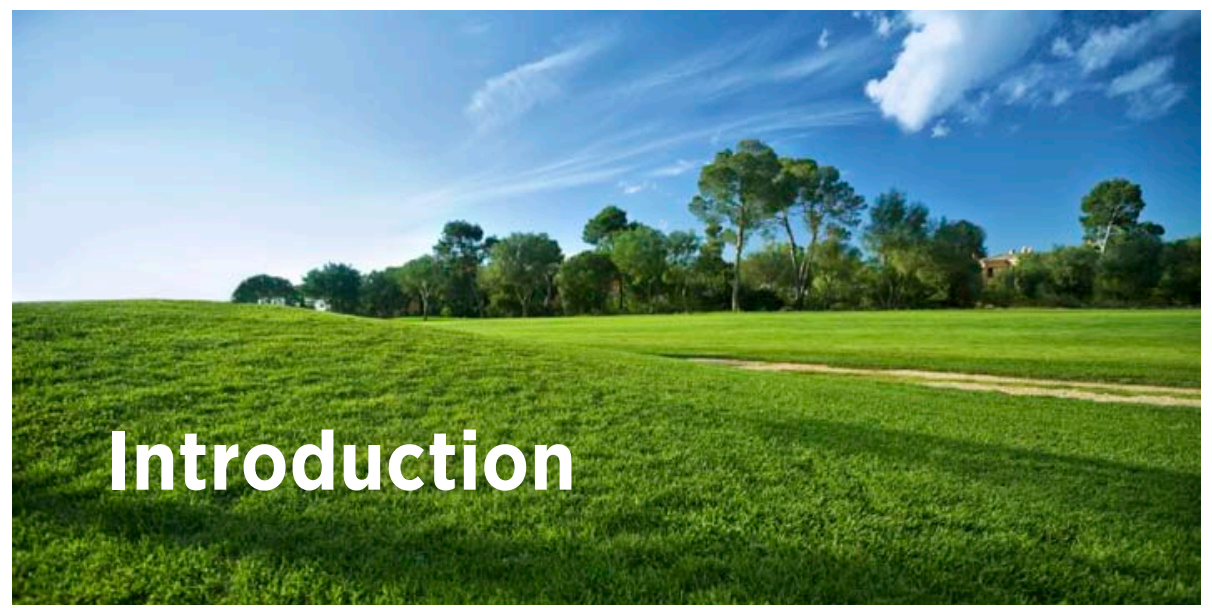

Photo from istock/6334062

Turf grass is a fixture of the American landscape and the American economy. It is the nation's largest irrigated crop, covering more than 40 million acres. Legions of lawnmowers care for this expanse during the growing season-up to year-round in the warmest climates. The annual economic impact of the U.S. turf grass industry has been estimated at more than $\$ 62$ billion.

Lawn mowing also contributes to the nation's petroleum consumption and pollutant emissions. Mowers consume 1.2 billion gallons of gasoline annually, about $1 \%$ of U.S. motor gasoline consumption. Commercial mowing accounts for about $35 \%$ of this total and is the highest-intensity use. Large property owners and mowing companies cut lawns, sports fields, golf courses, parks, roadsides, and other grassy areas for 7 hours per day and consume 900 to 2,000 gallons of fuel annually depending on climate and length of the growing season. In addition to gasoline, commercial mowing consumes more than 100 million gallons of diesel annually.

Alternative fuel mowers are one way to reduce the energy and environmental impacts of commercial lawn mowing. They can reduce petroleum use and emissions compared with gasoline- 


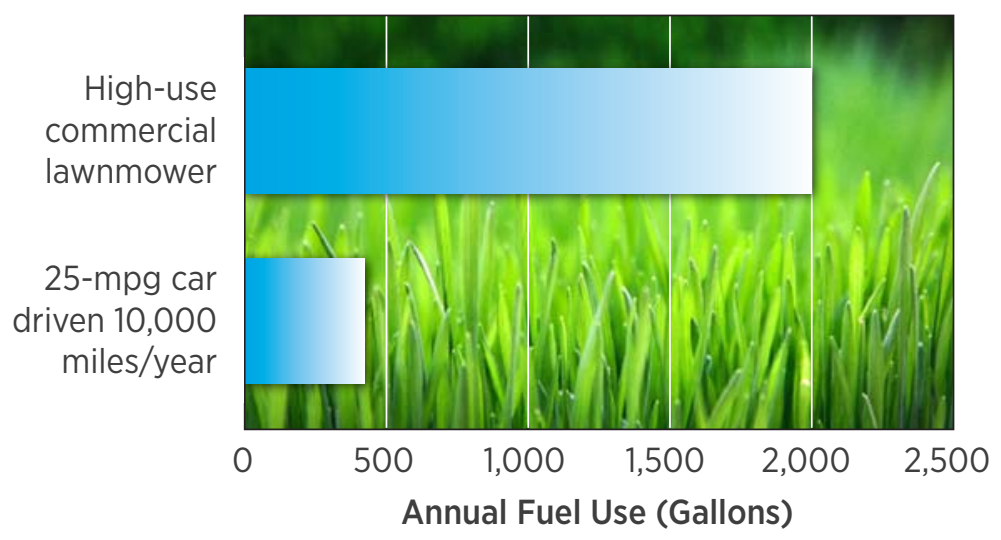

Commercial lawnmowers can consume more fuel than a typical car. Photo from istock/6751109

and diesel-fueled mowers. They may also save on fuel and maintenance costs, extend mower life, reduce fuel spillage and fuel theft, and promote a "green" image. And on ozone alert days, alternative fuel mowers may not be subject to the operational restrictions that gasoline mowers must abide by.

To help inform the commercial mowing industry about product options and potential benefits, Clean Cities produced this guide to alternative fuel commercial lawn equipment. Although the guide's focus is on original equipment manufacturer (OEM) mowers, some mowers can be converted to run on alternative fuels. For more information about propane conversions, see page 8.

This guide may be particularly helpful for organizations that are already using alternative fuels in their vehicles and have an alternative fuel supply or electric charging in place (e.g., golf cart charging stations at most golf courses). On the flip side, experiencing the benefits of using alternative fuels in mowing equipment may encourage organizations to try them in on-road vehicles as well. Whatever the case, alternative fuel commercial lawnmowers are a powerful and cost-effective way to reduce U.S. petroleum dependence and help protect the environment. 


\section{Compressed Natural Gas}

Virtually all natural gas consumed in the United States is produced in North America. And compared with gasoline and diesel engines, natural gas engines can produce lower amounts of harmful emissions, including the greenhouse gas carbon dioxide. The cleaner-burning nature of natural gas may result in reduced maintenance requirements, such as less-frequent oil changes, and extended mower life. In addition, natural gas does not spoil or clog fuel systems in lawn equipment during seasonal storage, whereas liquid fuels can.

Natural gas must be compressed and stored at high pressure to enable adequate mowing time. This sealed and pressurized fuel-storage system has the advantage of eliminating evaporative emissions and spillage, as well as the potential fuel theft sometimes associated with liquid-fueled lawn equipment.

In 2011, there were more than 900 compressed natural gas (CNG) fueling stations in the United States with stations in almost every state. See a national map of CNG stations and find stations near you using the Alternative Fuels and Advanced Vehicles Data Center (AFDC) at www.afdc.energy.gov/afdc/fuels/ natural_gas_locations.html. Over the past decade, CNG has been the least expensive U.S. motor fuel.

\section{Dixie Chopper}

- Website: www.dixiechopper.com

- Dealer Locator: www.dixiechopper.com

Xcaliber Eco-Eagle

- Cutting Deck Size: 66 in.

- Engine: Generac 990 cc

- Manufacturer's Suggested

Retail Price (MSRP): $\$ 20,599$

- Basic Commercial Warranty: 5 years

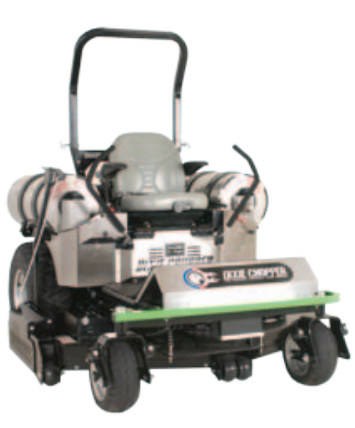

Photo from manufacturer

\section{Biodiesel}

Biodiesel is a renewable alternative fuel produced domestically from a wide range of vegetable oils and animal fats. It is nontoxic and can reduce pollutant emissions compared with petroleum diesel. It also improves engine operation by raising diesel fuel's lubricity and combustion quality. Biodiesel blended with petroleum diesel can be used to fuel diesel vehicles without modifying the vehicles in most cases-20\% biodiesel and $80 \%$ petroleum diesel (B20) is the most popular blend. B20 or other biodiesel blends are 
approved for use with some diesel-powered commercial lawnmowers without modification. Contact mower manufacturers to determine if B20 is approved for use in their diesel products.

\section{Electricity}

Electric power is quiet, requires little maintenance, and produces no tailpipe emissions. Electric mowers connected to an electricity supply with a cord or powered with rechargeable batteries are popular for residential use, but the rigors of commercial mowing have limited their use for this application to date. However, recent improvements in battery technology have resulted in new products with potential commercial application. Hustler Turf's Zeonthe first all-electric, zero-turn-radius mower-provides up to 80 minutes of continuous mowing time, enough to mow more than an acre. The Ariens AMP Rider provides up to 75 minutes of continuous mowing time.

\section{Ariens}

- Website: www.ampbyariens.com

- Dealer Locator: http://apache.ariens.com/cgibin/pnrg0140a

\section{AMP Rider}

- Cutting Deck Size: 34 in.

- Propulsion: Traction Drive, 4 horsepower (HP), 48 volts (V)

- MSRP: \$2,329

- Basic Commercial Warranty: 1 year for battery, 2 years for other components

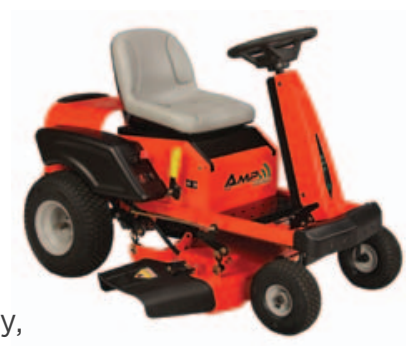

\section{Hustler Turf}

- Website: www.hustlerturf.com

- Dealer Locator: www.hustlerturf.com/find-a-dealer.htm/

\section{Zeon}

- Cutting Deck Size: 42 in.

- Propulsion: Hydro-Gear, $48 \mathrm{~V}$, 82 foot-pound maximum torque

- MSRP: \$6,999

- Basic Commercial Warranty: 1 year

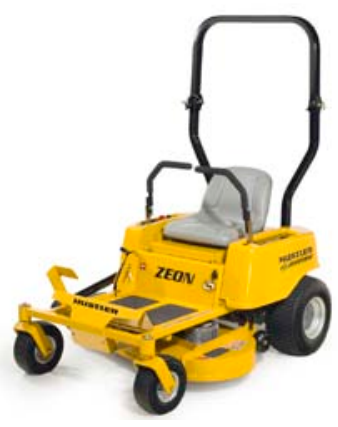

Photos from manufacturers 


\section{Propane}

Also known as liquefied petroleum gas or LPG and autogas, propane is a widely available alternative transportation fuel in the United States. There are more than 2,600 propane vehicle fueling stations with locations in all 50 states. See a national map of propane stations and find stations near you using the AFDC's Alternative Fueling Station Locator (www.afdc.energy.gov/ afdc/fuels/propane_locations.htm/). Most propane consumed in the United States is produced domestically, and, compared with gasoline and diesel engines, propane engines can produce lower amounts of some harmful emissions, including carbon dioxide. The cleaner-burning nature of propane may result in reduced maintenance requirements, such as less-frequent oil changes, and extended mower life. Also, like CNG, propane does not spoil or clog fuel systems in lawn equipment during seasonal storage, which can be the case with gasoline and diesel.

Propane is stored as a liquid under relatively low pressure and becomes a gas at normal pressure (meaning it enters the engine as a gas). The liquid storage gives it a high energy density, so a mower can run a long time on a tank of fuel, while the sealed and pressurized storage has the advantage of eliminating evaporative emissions and spillage as well as potential fuel theft.

There are two options in the propane arena: Buying an OEM propane mower, or converting a conventional one to run on propane. One company, EnviroGard, patented the propane technology found on OEM mowers from many manufacturers, converts gasoline mowers (and other gasoline-powered equipment) to propane, and supplies full propane engines to be installed in aftermarket mowers. The company's conversion kits range from $6.5 \mathrm{HP}$ to $37 \mathrm{HP}$.

Like OEM products, the conversions are certified by the U.S. Environmental Protection Agency. Contact the company to locate the nearest conversion center. Propane mower conversions cost $\$ 1,000$ to $\$ 2,500$, including parts and labor. For more information about EnviroGard, visit www.onyxsolutions. com/lawn-care.php. To find other companies that could perform propane mower conversions, contact your state's Propane Gas Association (see www.npga.org/i4a/pages/index.cfm?pageid=544 for a list of association websites) or use the Propane Education \& Research Council's (PERC) Find a Propane Retailer tool (www.usepropane.com/fpr.aspx). 


\section{Ariens/Gravely}

- Website: www.gravely.com

- Dealer Locator: www.gravelymower.com/locator

Pro-Master 260H XDZ LP

- Cutting Deck Size: 60 in.

- Engine: Generac 28 HP

- MSRP: \$13,049

- Basic Commercial Warranty: 2 years

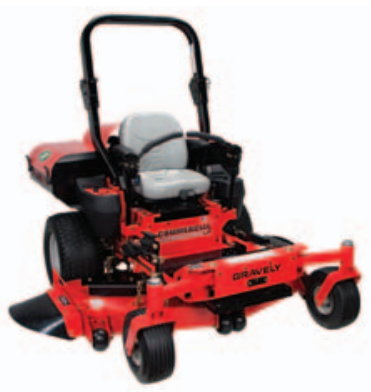

\section{Bob-Cat}

- Website: www.bobcatturf.com

- Dealer Locator: www.bobcatturf.com/Dealer_Locator

\section{Predator-Pro LP}

- Cutting Deck Size: 61 in. and 72 in.

- Engine: Generac $30 \mathrm{HP}$

- MSRP: \$13,372 (61-in. model) $\$ 14,279$ (72-in. model)

- Basic Commercial Warranty: 2 years/2,000 hours or 5 years/500 hours

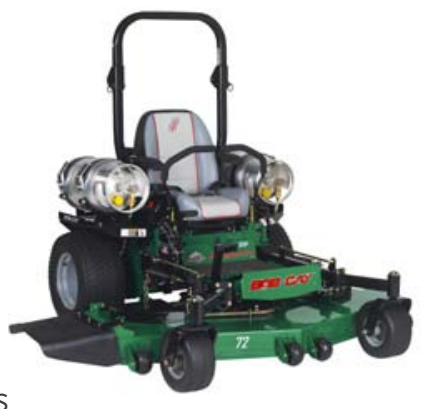

\section{Cub Cadet}

- Website: www.cubcadet.com

- Dealer Locator: www.cubcadet.com

TANK S LP

- Cutting Deck Size: 60 in. and 72 in.

- Engine: Kawasaki 852 cc (60-in. model) Kawasaki 999 cc (72-in. model)

- MSRP: \$15,199 (60-in. model) $\$ 16,199$ (72-in. model)

- Basic Commercial Warranty: 3 years

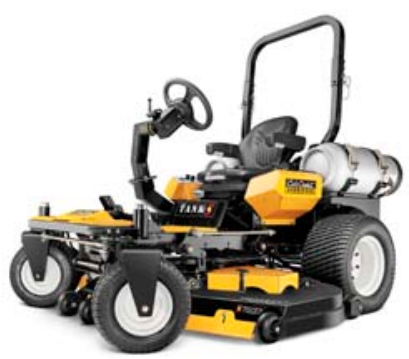


Cub Cadet continued

\section{Z Force S LP}

- Cutting Deck Size: 48 in. and 60 in.

- Engine: Kawasaki 726 cc

- MSRP: \$6,399 (48-in. model) $\$ 7,199$ (60-in. model)

- Basic Commercial Warranty: 3 years/180 hours

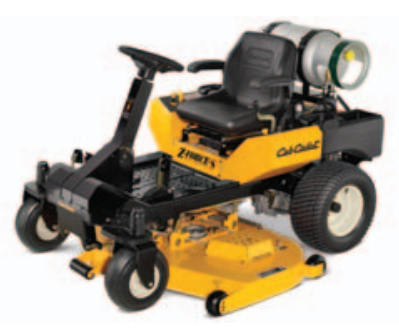

\section{Dixie Chopper}

- Website: www.dixiechopper.com

- Dealer Locator: www.dixiechopper.com

\section{Xcaliber Propane}

- Cutting Deck Size: 66 in. and 74 in.

- Engine: Generac 990 cc

- MSRP: \$14,199 (66-in. model) $\$ 14,299$ (74-in. model)

- Basic Commercial Warranty: 5 years

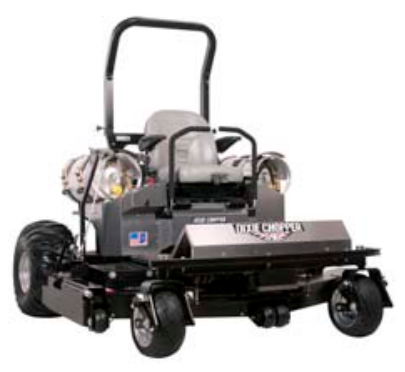

\section{Exmark}

- Website: www.exmark.com

- Dealer Locator: www.exmarkdealer.com

\section{Turf Tracer S-Series Propane}

- Cutting Deck Size: 48 in. and 52 in.

- Engine: Kawasaki 20 HP

- MSRP: $\$ 8,499$ (48-in. model) $\$ 8,699$ (52-in. model)

- Basic Commercial Warranty: 2 years

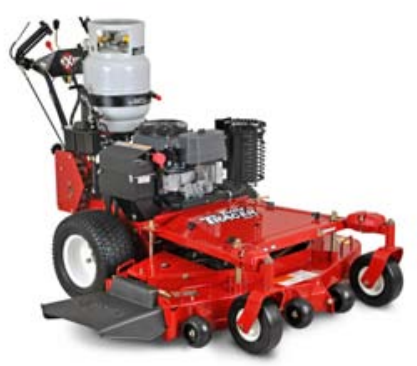




\section{Exmark continued}

\section{Turf Tracer X-Series Propane}

- Cutting Deck Size: 52 in. and 60 in.

- Engine: Kawasaki $24 \mathrm{HP}$

- MSRP: $\$ 9,898$ (52-in. model)

$\$ 9,998$ (60-in. model)

- Basic Commercial Warranty: 2 years

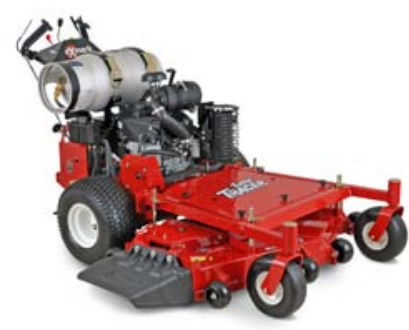

\section{Lazer Z S-Series Propane}

- Cutting Deck Size: 60 in. and 72 in.

- Engine: Kawasaki 29 HP

- MSRP: $\$ 12,899$ (60-in. model)

$\$ 13,399$ (72-in. model)

- Basic Commercial Warranty: 3 years

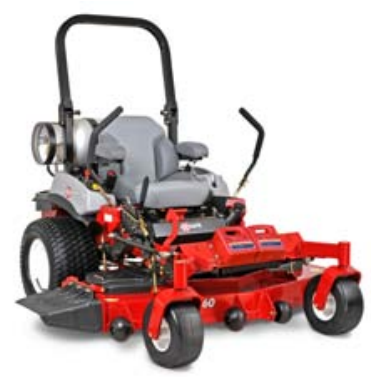

\section{Lazer Z X-Series Propane}

- Cutting Deck Size: 60 in.

- Engine: Kawasaki 29 HP

- MSRP: \$13,599

- Basic Commercial Warranty: 3 years

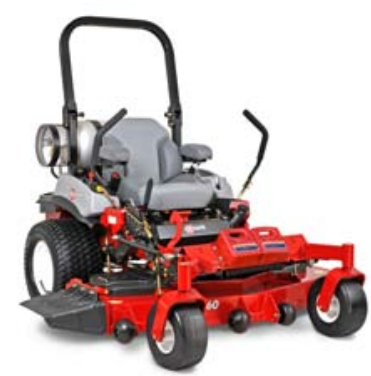

\section{Ferris Industries}

- Website: www.ferrisindustries.com

- Dealer Locator: http://ferris.via.infonow.net/locator

\section{IS3100ZP}

- Cutting Deck Size: 61 in. and 72 in.

- Engine: Briggs \& Stratton 895 cc

- MSRP: \$14,799 (61-in. model) $\$ 15,499$ (72-in. model)

- Basic Commercial Warranty: 2 years

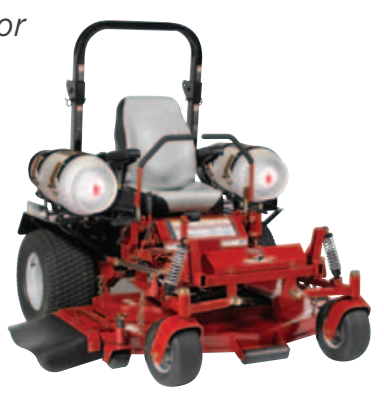




\section{Husqvarna}

- Website: www.husqvarna.com

- Dealer Locator:

www.husqvarna.com/us/landscape-andgroundcare/dealers/dealer-locator

\section{PZ6029PFX}

- Cutting Deck Size: 60 in.

- Engine: Kawasaki 29 HP

- MSRP: $\$ 11,499$

- Basic Commercial Warranty: 3 years

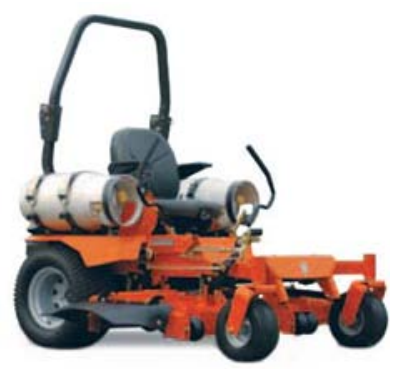

\section{SCAG Power Equipment}

- Website: www.scag.com

- Dealer Locator: www.scag.com/locator

\section{Turf Tiger LP}

- Cutting Deck Size: 52 in. and 61 in.

- Engine: Kohler

- MSRP: \$12,900 (52-in. model)

$\$ 13,065$ (61-in. model)

- Basic Commercial Warranty: 2 years

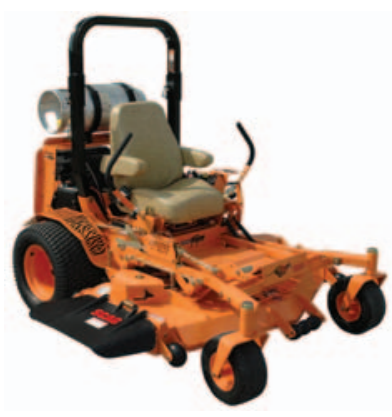

\section{Turf Tiger Dual Fuel}

- Cutting Deck Size: 61 in.

- Engine: Kubota Dual-Fuel 31 HP (gasoline), 29 HP (propane)

- MSRP: $\$ 18,425$

- Basic Commercial Warranty: 2 years

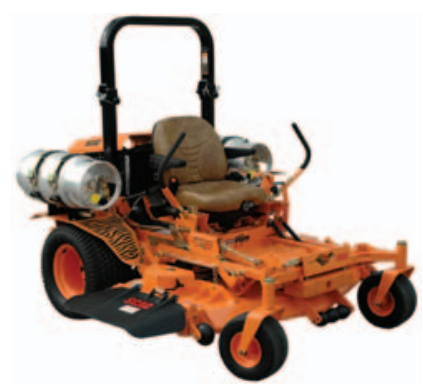




\section{Snapper Pro}

- Website: www.snapperpro.com

- Dealer Locator: http://snapperpro.via.infonow.net/locator

\section{S200xp}

- Cutting Deck Size: 61 in.

- Engine: Briggs \& Stratton $895 \mathrm{cc}$

- MSRP: \$10,999

- Basic Commercial Warranty: 2 years

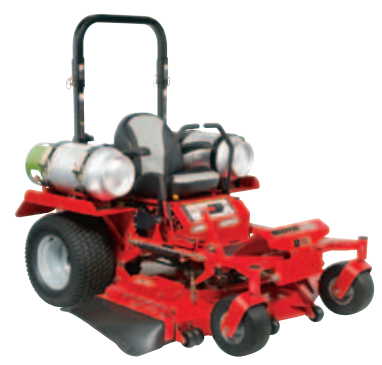

Toro

- Website: www.toro.com

- Dealer Locator: www.toro.com/en-us/locator

Z Master G3 Propane Powered

- Cutting Deck Size: 60 in. and 72 in.

- Engine: Kawasaki 29 HP

- MSRP: \$14,888 (60-in. model) $\$ 15,443$ (72-in. model)

- Basic Commercial Warranty:

5 years/1,200 hours

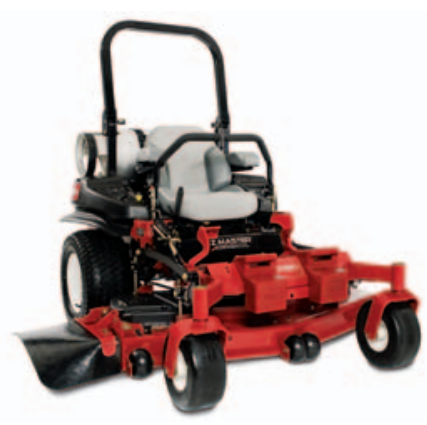

\section{Zipper Mowers}

- Website: www.zippermowers.com

\section{STS-28 LP}

- Cutting Deck Size: 64 in. and 74 in.

- Engine: Kawasaki 28 HP

- MSRP: \$12,799 (64-in. model) $\$ 13,499$ (74-in. model)

- Basic Commercial Warranty: 5 years

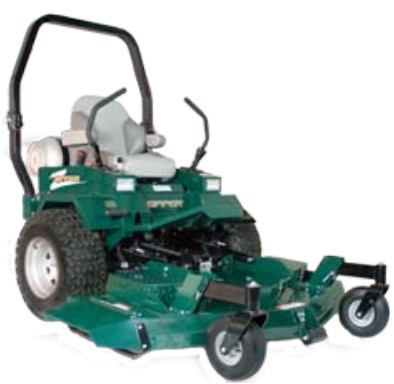


Zipper continued

ETS LP

- Cutting Deck Size: 50 in. and 60 in.

- Engine: Kawasaki $31 \mathrm{HP}$

- MSRP: \$10,699 (50-in. model) $\$ 11,499$ (60-in. model)

- Basic Commercial Warranty: 5 years

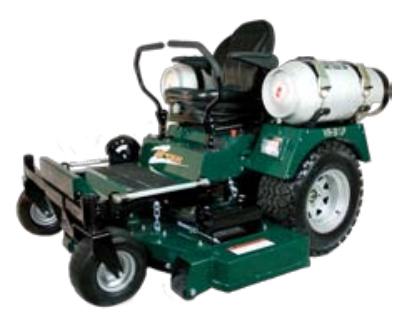

Photo from manufacturer

\section{Incentives}

Various financial incentives may be available for alternative fuels and alternative fuel mowers. For example, the Propane Council of Texas provided incentives for the purchase of dedicated propane mower purchases or conversions. See www.txpropane.com/propanetexasfueltexasproudpro panelawnmower.htm/ for more information about this program. A similar program run through the Central Texas Clean Cities Coalition incentivized 55 propane mower conversions and purchases. PERC offered incentives for the purchase of new propane mowers through its Propane FEED (Farm Equipment Efficiency Demonstration) program. See www.agpropane.com/FEED for more information.

Alternative fuel mowers also may be eligible for some federal and state incentives that are available for alternative fuel vehicles. See the AFDC's Federal and State Incentives and Laws section at www.afdc.energy.gov/ afdc/laws for more information about other incentives that may apply to alternative fuel mowers.

Another incentive is the unrestricted use of clean alternative fuel mowers on "ozone action days" in some cities. These are days when high ozone pollution levels trigger restrictions on operation of conventional fuel mowers, but alternative fuel mowers are left to operate freely because of their clean-burning characteristics. This gives alternative fuel mower operators an advantage over competitors who use conventional fuels only.

\section{Special Considerations}

Some mower engines are designed to run on alternative fuels with little or no modification. Others are not. Using alternative fuels or fuel blends that are not specifically approved for your equipment can cause serious damage to the engine or significantly reduce performance. To ensure alternative fuel or fuel blend use won't damage your mower, be sure to consult your equipment's owner's manual or contact the manufacturer or dealer. 


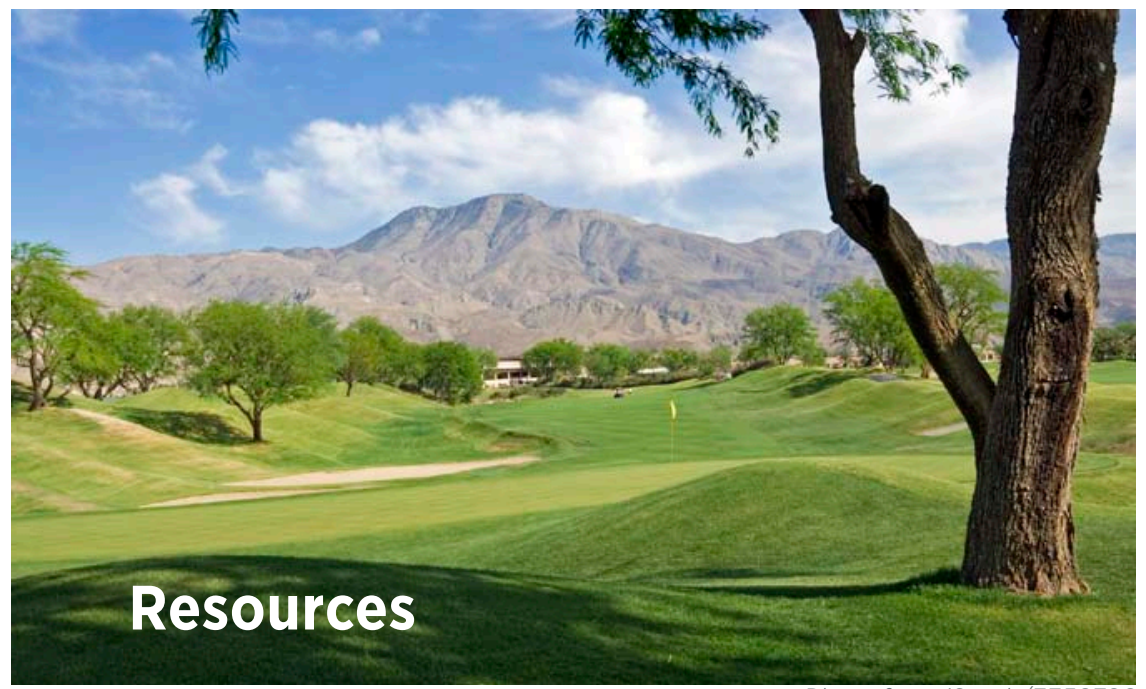

Photo from istock/3358788

Visit the following websites for more information about alternative fuels and alternative fuel lawnmowers.

All Propane Mowers: www.allpropanemowers.com

Alternative Fuels and Advanced Vehicles Data Center: www.afdc.energy.gov/afdc

AmeriGas: www.amerigas.com

Blossman Gas: www.propanemowerfueling.com

Ferrellgas: $w w w . f e r r e l l g a s . c o m$

Heritage Propane: www.heritagepropane.com

Metro Lawn: www.gogreenmetrolawn.com

National Propane Gas Association: www.npga.org

Natural Gas Vehicles for America (NGVAmerica): WWW.ngvc.org

Propane Education \& Research Council: www.propanecouncil.org

Texas Propane Gas Association/Propane Council of Texas: www.txpropane.com 
Energy Efficiency \& Renewable Energy

Clean Cities Technical Response Service 800-254-6735

technicalresponse@icfi.com

Prepared by the National Renewable Energy Laboratory (NREL), a national laboratory of the U.S. Department of Energy, Office of Energy Efficiency and Renewable Energy; operated by the Alliance for Sustainable Energy, LLC.

DOE/GO-102011-3364

October 2011 